\title{
Analysis of Causes of Dependency Under the Long Term Care Insurance Scheme in Japan
}

\author{
Shinya Matsuda, Yoshihisa Fujino, Junko Yano \\ Department of Preventive Medicine and Community Health, University of Occupational and Environmental \\ Health
}

\begin{abstract}
After the introduction of the Long Term Care Insurance (LTCI), the number of persons who received the LTCI services increased very rapidly. This causes a rapid increase in LTCI expenditures and premium. In order to make LTCI scheme sustainable, it is pivotal how to maintain the ADL and health level of the elderly. For this purpose, we have investigated the causes of dependency among the LTCI users in order to establish an appropriate preventive strategy. The materials were LTCI related data (assessment sheet and physician's opinion report) of 2002 whole year of K city, Fukuoka. Total number of data is 30,562 cases. The cases were stratified by diagnosis, LTCI eligibility level, and type of residence. There are interesting differences in causal diagnoses according to the eligibility level. In the case of slightly frail elderly, the osteo-muscular disorders are the most important causes of dependency. On the contrary, among the severely frail elderly, the cerebro-vascular diseases (CVD) were the most important. The number of users with dementia increases along with LTCI level. Considering that the largest increase in LTCI users has been observed in the slightly frail elderly, it is very important to organize a ADL prevention program focusing to osteo-muscular disorders, such as a community based physical fitness class.
\end{abstract}

Key words: frailty, prevention, Long Term Care Insurance, osteo-muscular disorder, CVA, Japan

\section{Introduction}

Japan is now facing to a rapid graying of society. It is estimated that the percentage of population over 65 years old will be over $30 \%$ in 2025 .

With fewer children, more women working, and changing attitude toward family responsibilities, the traditional system of informal care-giving is widely perceived as inadequate to take care of the increasing number of the frail elderly. This situation naturally requires the socialization of care, and finally in 2000, the Japanese government implemented the Long

\footnotetext{
Received: July 12, 2007

Accepted: August 24, 2007

Correspondence: S. Matsuda, Department of Preventive Medicine and Community Health, School of Medicine, University of Occupational and Environmental Health, 1-1 Iseigaoka, Yahata-nishi-ku, Kitakyushu, Fukuoka 807-8555, Japan

e-mail: smatsuda@med.uoeh-u.ac.jp
}

Term Care Insurance (LTCI) as a new scheme for the frail elderly ${ }^{1)}$.

LTCI has been welcomed by citizen, and number of persons who received the LTCI services increased from 2,200 thousands in 2,000 to 4,000 thousands in 2004 as shown in Figure 12). This naturally causes a rapid increase in LTCI expenditures and premium.

The largest increase was observed in persons categorized into "care required 1" and "assistance required" (Figure 1). The latter category was set in order to prevent the ADL degradation among the slightly frail elderly. However, Shimane-JMARI study has clarified that the worsening of ADL level was the largest among this category ${ }^{3}$. This fact means the preventive services provided by LTCI scheme had little effect for ADL maintenance among the slightly frail elderly.

In order to make LTCI scheme sustainable, it is pivotal how to maintain the ADL land health level of the elderly. It is quite reasonable to invesigate the 


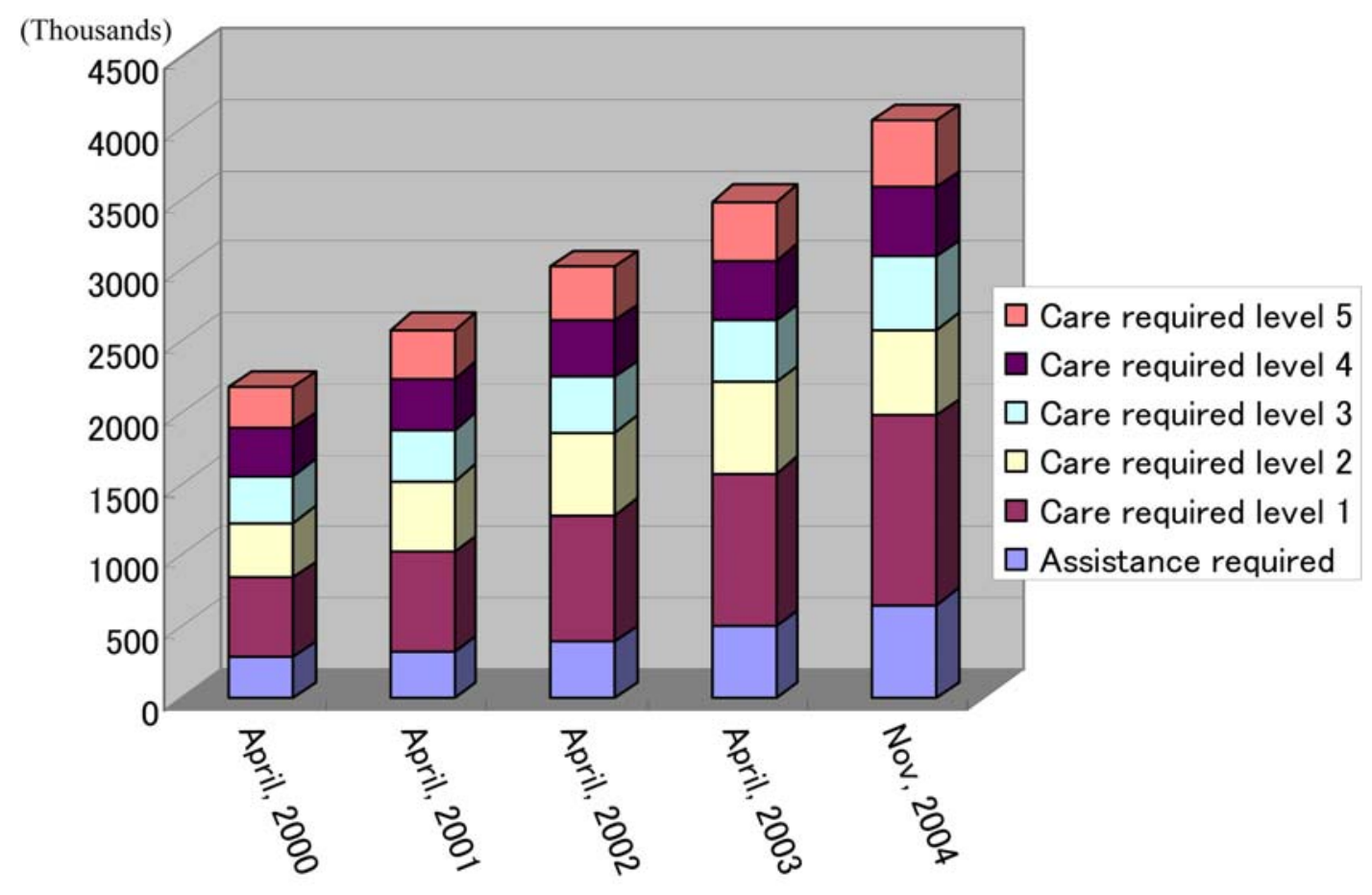

Source: MHLW (2005)

Figure 1. Chronological changes in the beneficiaries of LTCI

causes of dependency among the LTCI users in order to establish an appropriate strategy.

In this study, the authors have investigated the LTCI assesment sheet and Physician's opinion report in order to clarify the causes of independency among the frail elderly living in a local government of Fukuoka prefecture, Japan.

\section{Material and Method}

\section{Material}

The study was organized as a joint research project of $\mathrm{K}$ city and our department. Before starting the program, the contract on security issues was signed and the approval of ethical committee of our university was obtained.

The materials were LTCI related data (assessment sheet and physician's opinion report) of 2002 whole year of $\mathrm{K}$ city, Fukuoka. Total number of data is 30,562 cases. In order to assure the security of privacy, the original data were processed in the LTCI department of $\mathrm{K}$ city office and the anonymous data set was created for the study.

From the LTCI assessment sheet, demographic information such as age, sex, residential area (primary school zone), residence type (home or institution), LTCI eligibility level was derived. Diagnosis related to dependency was derived from physician's opinion report. All diagnosis was coded using the social insurance disease code ${ }^{\text {Note }} 1$.

\section{Method}

The causal diseases were stratified by diagnosis, LTCI eligibility level, and type of residence.

$\mathrm{K}$ city composes of 7 wards. In order to clarify the standardized disease structures of each ward, the Standardized Responsible Disease Prevalence Ratio (SRDPR) was calculated. The formula is as follows:

SRDPR of Diagnosis Xin j ward $=\mathrm{N}_{\mathrm{j}} / \Sigma \Sigma\left(\mathrm{SPR}_{\mathrm{ik}} \times \mathrm{TN}_{\mathrm{ik}}\right)$

Where,

$\mathrm{N}_{\mathrm{j}}=$ number of cases with diagnosis $X$ in ward $\mathrm{j}$,

$\mathrm{SPR}_{\mathrm{ik}}=$ Prevalence of diagnosis $\mathrm{X}$ among the reference population ( $\mathrm{K}$ city total) of age category i, and LTCI category k,

$\mathrm{TN}_{\mathrm{i}}=$ number of aged with age category $\mathrm{i}$ and LTCI category $\mathrm{k}$.

The statistical analyses were conducted by SPSS ver.10.0J. 
Table 1 Number of aged stratified by LTCI eligibility level and place of care (2002)

\begin{tabular}{|c|c|c|c|c|c|c|c|c|}
\hline & & $\begin{array}{l}\text { Assistance } \\
\text { required }\end{array}$ & $\begin{array}{c}\text { Care required } \\
\text { level } 1\end{array}$ & $\begin{array}{c}\text { Care required } \\
\text { level } 2\end{array}$ & $\begin{array}{c}\text { Care required } \\
\text { level } 3\end{array}$ & $\begin{array}{c}\text { Care required } \\
\text { level } 4\end{array}$ & $\begin{array}{c}\text { Care required } \\
\text { level } 5\end{array}$ & Total \\
\hline \multirow[t]{2}{*}{ At Home } & $\mathrm{N}$ & 3423 & 8079 & 3922 & 2023 & 1203 & 761 & 19411 \\
\hline & $\%$ & $17.6 \%$ & $41.6 \%$ & $20.2 \%$ & $10.4 \%$ & $6.2 \%$ & $3.9 \%$ & $100.0 \%$ \\
\hline \multirow[t]{2}{*}{ Institutionalized } & $\mathrm{N}$ & 184 & 1643 & 1792 & 1876 & 2267 & 1883 & 9645 \\
\hline & $\%$ & $1.9 \%$ & $17.0 \%$ & $18.6 \%$ & $19.5 \%$ & $23.5 \%$ & $19.5 \%$ & $100.0 \%$ \\
\hline \multirow[t]{2}{*}{ Total } & $\mathrm{N}$ & 3607 & 9722 & 5714 & 3899 & 3470 & 2644 & 29056 \\
\hline & $\%$ & $12.4 \%$ & $33.5 \%$ & $19.7 \%$ & $13.4 \%$ & $11.9 \%$ & $9.1 \%$ & $100.0 \%$ \\
\hline
\end{tabular}

Table 2 Causal diseases of dipendency stratified by LTCI eligibility level and place of care

\begin{tabular}{|c|c|c|c|c|c|c|}
\hline $\begin{array}{l}\text { Home } \\
\text { care }\end{array}$ & $\begin{array}{l}\text { Assistance } \\
\text { required }\end{array}$ & $\begin{array}{c}\text { Care required } \\
\text { level } 1\end{array}$ & $\begin{array}{c}\text { Care required } \\
\text { level } 2\end{array}$ & $\begin{array}{c}\text { Care required } \\
\text { level } 3\end{array}$ & $\begin{array}{c}\text { Care required } \\
\text { level } 4\end{array}$ & $\begin{array}{c}\text { Care required } \\
\text { level } 5\end{array}$ \\
\hline First & Hypertention & Hypertention & Hypertention & $\begin{array}{l}\text { Cerebral } \\
\text { Infarction }\end{array}$ & $\begin{array}{l}\text { Cerebral } \\
\text { Infarction }\end{array}$ & $\begin{array}{l}\text { Cerebral } \\
\text { Infarction }\end{array}$ \\
\hline Second & Arthritis & Arthritis & $\begin{array}{l}\text { Cerebral } \\
\text { Infarction }\end{array}$ & Hypertention & Dementia & Dementia \\
\hline Third & $\begin{array}{l}\text { Degeneration } \\
\text { of bone }\end{array}$ & $\begin{array}{l}\text { Cerebral } \\
\text { Infarction }\end{array}$ & Dementia & Dementia & Hypertention & Hypertention \\
\hline $\begin{array}{l}\text { Institutional } \\
\text { care }\end{array}$ & $\begin{array}{l}\text { Assistance } \\
\text { required }\end{array}$ & $\begin{array}{c}\text { Care required } \\
\text { level } 1\end{array}$ & $\begin{array}{c}\text { Care required } \\
\text { level } 2\end{array}$ & $\begin{array}{c}\text { Care required } \\
\text { level } 3\end{array}$ & $\begin{array}{c}\text { Care required } \\
\text { level } 4\end{array}$ & $\begin{array}{c}\text { Care required } \\
\text { level } 5\end{array}$ \\
\hline First & Hypertention & $\begin{array}{l}\text { Cerebral } \\
\text { Infarction }\end{array}$ & $\begin{array}{l}\text { Cerebral } \\
\text { Infarction }\end{array}$ & Dementia & $\begin{array}{l}\text { Cerebral } \\
\text { Infarction }\end{array}$ & $\begin{array}{l}\text { Cerebral } \\
\text { Infarction }\end{array}$ \\
\hline Second & $\begin{array}{l}\text { Cerebral } \\
\text { Infarction }\end{array}$ & Hypertention & Dementia & $\begin{array}{l}\text { Cerebral } \\
\text { Infarction }\end{array}$ & Dementia & Dementia \\
\hline Third & $\begin{array}{l}\text { Degeneration } \\
\text { of bone }\end{array}$ & Dementia & Hypertention & Hypertention & Hypertention & Hypertention \\
\hline
\end{tabular}

\section{Results}

\section{Basic statistics}

Table 1 shows the distribution of the LTCI users categorized by LTCI eligibility level and residence type. Among 29,056 LTCI applicants, 19,411 $(66.8 \%)$ lived in their home and another 9,645 (33.2\%) were in institution.

In total, the largest number was observed in "care required 1", followed by "care required 2", "care required 3", "assistance required", "care required 4", "care required 5" and "non-eligible".

For users living in their home, the largest number was observed in "care required 1", followed by "care required 2", "care required 3", "assistance required", "care required 4", "care required 5" and "non-eligible".

In the case of users institutionalized, the largest number was observed in "care required 4", followed by "care required 5", "care required 3", "care required 2", "care required 1", "assistance required", and "noneligible".

\section{Diseases responsible for dependency}

Table 2 shows the distribution of LTCI users stratified by LTCI eligibility level, diagnosis and residence type. It is very interesting to know that causal diagnoses are different according to the eligibility 
Table 3 Standardized responsible disease prevalence ratio of each ward of K city, Fukuoka

\begin{tabular}{|c|c|c|c|c|c|c|c|c|c|c|c|c|c|c|c|c|}
\hline & \multirow[b]{2}{*}{$\mathrm{N}$} & \multirow{2}{*}{$\frac{\mathrm{K} \text { city, all }}{5027}$} & \multicolumn{2}{|c|}{ Ward 1} & \multicolumn{2}{|c|}{ Ward 2} & \multicolumn{2}{|c|}{ Ward 3} & \multicolumn{2}{|c|}{ Ward 4} & \multicolumn{2}{|c|}{ Ward 5} & \multicolumn{2}{|c|}{ Ward 6} & \multicolumn{2}{|c|}{ Ward 7} \\
\hline & & & 595 & SRDPR & 890 & SRDPR & 762 & SRDPR & 517 & SRDPR & 499 & SRDPR & 1293 & SRDPR & 471 & SRDPR \\
\hline & $\%$ & $2.6 \%$ & $2.2 \%$ & 0.867 & $2.5 \%$ & 0.974 & $2.3 \%$ & 0.873 & $2.8 \%$ & 1.100 & $2.4 \%$ & 0.946 & $2.8 \%$ & 1.070 & $3.5 \%$ & 1.351 \\
\hline \multirow[t]{2}{*}{ Arthritis } & $\mathrm{N}$ & 3964 & 464 & SRDPR & 687 & SRDPR & 507 & SRDPR & 378 & SRDPR & 451 & SRDPR & 1086 & SRDPR & 391 & SRDPR \\
\hline & $\%$ & $2.0 \%$ & $1.7 \%$ & 0.858 & $1.9 \%$ & 0.953 & $1.5 \%$ & 0.737 & $2.1 \%$ & 1.020 & $2.2 \%$ & 1.085 & $2.3 \%$ & 1.140 & $2.9 \%$ & 1.422 \\
\hline \multirow[t]{2}{*}{ Dimentia } & $\mathrm{N}$ & 2909 & 425 & SRDPR & 525 & SRDPR & 459 & SRDPR & 261 & SRDPR & 274 & SRDPR & 755 & SRDPR & 210 & SRDPR \\
\hline & $\%$ & $1.5 \%$ & $1.6 \%$ & 1.070 & $1.5 \%$ & 0.992 & $1.4 \%$ & 0.909 & $1.4 \%$ & 0.960 & $1.3 \%$ & 0.898 & $1.6 \%$ & 1.080 & $1.6 \%$ & 1.041 \\
\hline \multicolumn{2}{|c|}{$\begin{array}{l}\mathrm{N} \text { of 1st category } \\
\text { insured }\end{array}$} & $\begin{array}{l}194498 \\
100.0 \%\end{array}$ & \multicolumn{2}{|c|}{26549} & \multicolumn{2}{|c|}{35368} & \multicolumn{2}{|c|}{$\begin{array}{c}33757 \\
\end{array}$} & \multicolumn{2}{|c|}{18177} & \multicolumn{2}{|c|}{$\begin{array}{c}20398 \\
\end{array}$} & \multicolumn{2}{|c|}{46758} & \multicolumn{2}{|c|}{$\begin{array}{c}13491 \\
100.0 \%\end{array}$} \\
\hline
\end{tabular}

SRDPR: Standardized Responsible Disease Prevalence Ratio. See text for Formula.

level. In the case of slightly frail elderly, the osteomuscular disorders are the most important causes of dependency. On the contrary, among the severely frail elderly, the cerebro-vascular diseases (CVD) were the most important. The number of users with dementia increases along with LTCI level.

\section{Standardized Responsible Disease Prevalence Ratio (SRDPR)}

Table 3 shows the results of SRDPR calculation for each of 7 wards in $\mathrm{K}$ city. There were considerable differences in ratios. In the case of Wards 7, SRDPR were 1.351 for cerebral infarction, 1.422 for arthritis, and 1.041 for dementia. This means that the aged living in Ward 7 become dependent 35\% more than reference group by cerebral infarction, $42 \%$ more by arthritis and $4 \%$ more by dementia.

These results indicate that preventive activities focused on the two important diseases, CVA and osteo-muscular diseases are very necessary in Ward 7.

\section{Discussion}

The present study has clarified that causal diseases of dependency are different between the slightly and severely frail elderly. In the case of slightly frail elderly, the osteo-muscular disorders are the most important causes of dependency. On the contrary, among the severely frail elderly, the cerebro-vascular diseases (CVD) were the most important. The number of aged with dementia increases along with LTCI eligibility level.

According to the official statistics, number of persons who received the LTCI services increased from 2,200 thousands in 2,000 to 4,000 thousands in 2004, and the largest increase was observed in persons categorized into "care required 1" 1 ).

As shown by our current study, the most common disorder among this category is osteo-muscular disorders, especially knee-joint problems. According to our previous study, the elderly with knee-joint problems had 2 times more possibility to have other ADL and health problems, such as toileting and mental autonomy $^{4}$. Furthermore, 60 to $80 \%$ of frail elderly evaluated as non-eligible for LTCI scheme have the osteo-muscular problems, such as knee joint problem and back pain.

The Ministry of Health, Labor and Welfare (MHLW) has focused to this problem and launched a new disease concept, "Disuse syndrome" or "Sedative life related diseases". Figure 2 shows the concept of disease. When the aged loses his/her autonomy of mobility, his/her activity is limited. This situation will be followed by depressive emotion, decrease in his/ her raison d'être and then mobility. In order to maintain or ameliorate the QOL of frail aged, it is very important to cut this vicious cycle. The preventive physical fitness program for the aged is expected to have this positive effect. Considering the results of present research, the $\mathrm{K}$ city office has launched the physical fitness program for the frail aged as shown in Figure 3 and Figure 4. Although the sample size is too small to derive some definitive conclusion, the initial results are very encouraging. Most of participants showed a statistically significant improvement for their physical fitness level such as maximal isometric knee extension strength, balance scale, and walking speed $^{5}$. Similar results have been accumulated in the other population $^{6-10)}$.

Considering the fact that the baby-boomer will enter into their old age within the coming decades, it is indispensable to organize some health promotion programs focusing on mobility. For this purpose, the Japanese Ministry of Health, Labor and Welfare (MHLW) has introduced a special program of preventive physical fitness by 2006 LTCI reform. According 


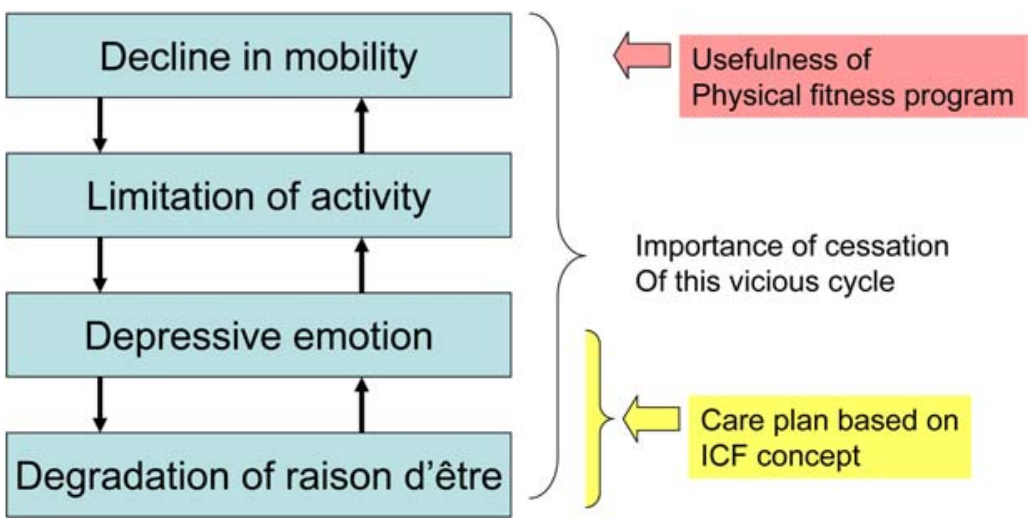

Figure 2. Concept of Sedative life diseases

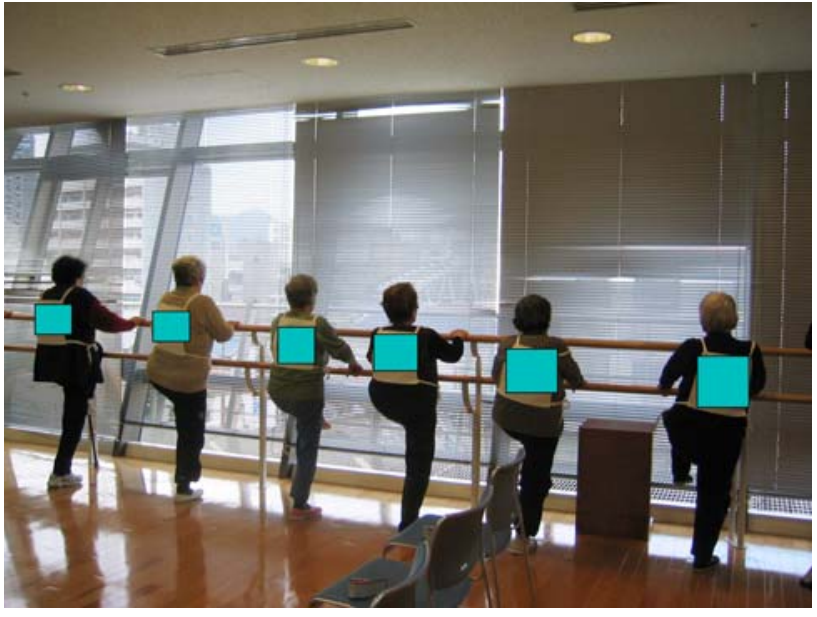

Figure 3. Physical fitness class by group exercises for the frail elderly (K city, Fukuoka)

to the new scheme, the frail elderly can receive a preventive physical fitness training under the LTCI scheme, if they are evaluated as "appropriate target".

In the case of prevention of CVA, it is necessary to organize some preventive program from the younger age. Especially control of hypertension and hyperlipidemia is very important. It is well known that reduced salt content in meals prevents hypertension. MHLW recommends that dietary salt intake should be reduced to less than $10 \mathrm{~g}$ per day. The Japanese Society of Hypertension suggested that 1-gram reduction of daily salt intake is expected to lower blood pressure by about $10 \mathrm{mmHg} / \mathrm{dl}$ and decrease the death due to stroke by $3 \%{ }^{11)}$. It is also recommended to take more potassium that has an effect to increase the urinary excretion of salts ${ }^{11)}$.

Another important strategy to reduce stroke death is to reduce the persons with hyperlipidemia. Accord-

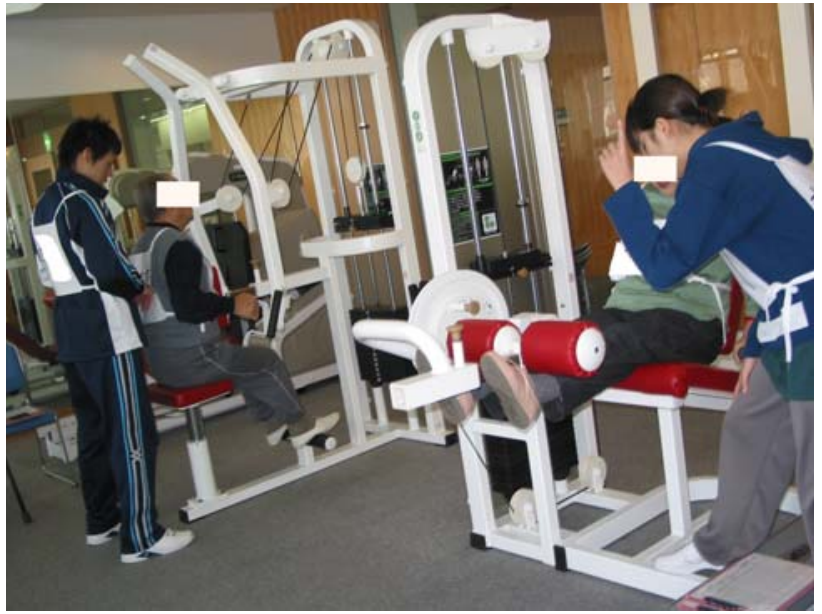

Figure 4. Physical fitness class by machine exercises for the frail elderly (K city, Fukuoka)

ing to the statistics of MHLW, the most frequent abnormality detected by the annual health check-up under the Law of Occupational Safety and Health is hyperlipidemia. In 2004 statistics, $28.7 \%$ of workers had a problem of hyperlipidemie ${ }^{12)}$. There is a problem of westernization of dietary habit behind this situation.

According to the 2006 health care reform, the specified health checkup and follow-up health guidance and intervention program will be introduced from 2008. All public health insurers have to organize health check-up and the following health promotion programs for the insured over 40 years old. The main target of screening is "Metabolic syndrome". If an insured is evaluated as high risk group and then "health guidance required", he/she must follow a standardized disease management program that is offered by the health support organization contracted with the 
insures. This new program is expected to reduce the high risk group of life-style related diseases, i.e. stroke, ischemic heart diseases, diabetes, which will be followed by the decrease in the number of dependent aged under the LTCI scheme.

Up to now, there has been no sufficient evidence to support this optimistic hypothesis. It is a social experimentation. We have to critically evaluate the effectiveness of program and if necessary to suggest some modification for better strategy.

The results of our study clarified that the prevention of ADL decline due to osteo-muscular disorder and CVA is the most important program in order to control the health expenditures and to maintain the QOL of the aged. In order to establish a really effective strategy, it is necessary to integrate the preventive activities organized under the different schemes, i.e. LTCI and the new law of medical service for the aged.

\section{References}

1) Matsuda $S$ : The health and social system for the aged in Japan. Aging Clin Exp Res 14 (4): 265-270 (2002).

2) Japan Association of Geriatric Health Services Facilities (ed): White paper on Long Term Care (Kaigo-hakusyo) 2004, Gyosei, 2006 (in Japanese).

3) Bureau of Health and Welfare of Shimane Prefecture: Repot on effectiveness of LTCI services (2003) (in Japanese).

4) Matsuda S: Introduction for Prevention of ADL degradation (Kaigo Yobo Nyumon), Syakai-hoken Kenkyujo (2006) (in Japanese).

5) Health and Welfare Bureau of Kitakyushu City:
Report on effective ADL preventive care program (2005) (in Japanese).

6) Fiatarone MA, O'Neill EF, Ryan ND, et al.: Exercise training and nutritional supplementation for physical frailty in very elderly people. N Engl J Med 330: 1769-1775 (1994).

7) Cambell AJ, Robertson MC, Gardner MM, et al.: Randomized controlled trial of a general practice programme of home based exercise to prevent falls in elderly women. BMJ 315: 1065-1069 (1997).

8) Fujita K, Nagatomi R, Hozawa A, et al.: Exercise training on physical activity in older people: a randomized control trial. J Epidemiol, 13: 120-126 (2003).

9) Yamamoto M, Shin T, Nakazono T, et al.: The effects of an exercise programs for the female elderly in the community. Journal of UOEH 27: 339348 (2005) (in Japanese).

10) Yano J, Ibayashi H, Nishiyama T, et al.: Functional improvement program of musculoskeletal system of the elderly in an isolated island of Kagoshima prefecture. Journal of UOEH 28: 229-237 (2006) (in Jaanese).

11) The Japanese Society of Hypertension: Report of Gen-En Working group (2006) (in Japanese).

12) Jisha: General Guidebook on Industrial Health 2005, Tokyo: Jisha (2005) (in Japanese).

\section{Note}

1. MHLW uses a special coding system for the social insurance statistics. All diseases are categorized into one of 119 disease categories. Each category corresponds to ICD classification. 